\title{
Challenges and recommendations in mapping of glacier parameters from space: results of the 2008 Global Land Ice Measurements from Space (GLIMS) workshop, Boulder, Colorado, USA
}

\author{
Adina E. RACOVITEANU, ${ }^{1,2,3}$ Frank PAUL, ${ }^{4}$ Bruce RAUP, $^{3}$ Siri Jodha Singh KHALSA, ${ }^{3}$ \\ Richard ARMSTRONG ${ }^{3}$ \\ ${ }^{1}$ Department of Geography, University of Colorado, Boulder, CO 80309-0260, USA \\ E-mail: racovite@colorado.edu \\ ${ }^{2}$ Institute of Arctic and Alpine Research, University of Colorado, Boulder, CO 80309-0450, USA \\ ${ }^{3}$ National Snow and Ice Data Center, University of Colorado, Boulder, CO 80309-0449, USA \\ ${ }^{4}$ Department of Geography, University of Zürich-Irchel, Winterthurerstrasse 190, CH-8057 Zürich, Switzerland
}

\begin{abstract}
On 16-18 June 2008 the US National Snow and Ice Data Center held a GLIMS workshop in Boulder, CO, USA, focusing on formulating procedures and best practices for operational glacier mapping using satellite imagery. Despite the progress made in recent years, there still remain many cases where automatic delineation of glacier boundaries in satellite imagery is difficult, error prone or timeconsuming. This workshop identified six themes for consideration by focus groups: (1) mapping clean ice and lakes; (2) mapping ice divides; (3) mapping debris-covered glaciers; (4) assessing changes in glacier area and elevation through comparisons with older data; (5) digital elevation model (DEM) generation from satellite stereo pairs; and (6) accuracy and error analysis. Talks presented examples and work in progress for each of these topics, and focus groups worked on compiling a summary of available algorithms and procedures to address and avoid identified hurdles. Special emphasis was given to establishing standard protocols for glacier delineation and analysis, creating illustrated tutorials and providing source code for available methods. This paper summarizes the major results of the 2008 GLIMS workshop, with an emphasis on definitions, methods and recommendations for satellite data processing. While the list of proposed methods and recommendations is not comprehensive and is still a work in progress, our goal here is to provide a starting point for the GLIMS regional centers as well as for the wider glaciological community in terms of documentation on possible pitfalls along with potential solutions.
\end{abstract}

\section{INTRODUCTION}

The major aim of the Global Land Ice Measurements from Space (GLIMS) initiative is to generate a global snapshot of digital glacier outlines from satellite data and make them available to the wider scientific community via the internet (Kargel and others, 2005; Raup and others, 2007b). Given the declining glacier mass on a global scale (Lemke and others, 2007; WGMS, 2007, 2008), the increasing importance of glacier meltwater as a water resource in the dry season in areas such as the Himalaya (Singh and others, 1997; Singh and Jain, 2002; Singh and Bengtsson, 2004; Barnett and others, 2005) and the Andes (Bradley and others, 2006), as well as the contribution of alpine glaciers to global sea-level rise (Arendt and others, 2002; Rignot and others, 2003; Raper and Braithwaite, 2006; Meier and others, 2007), global glaciological data are required for four main reasons:

1. The World Glacier Inventory (WGI) was compiled from aerial photography, maps and satellite imagery acquired during the 1960s and 1970s and is not complete with respect to detailed glaciological information (World Glacier Monitoring Service, 1989). Furthermore, glaciers in the WGI database are represented by point data rather than glacier outlines, making change detection for individual glaciers nearly impossible.

2. Data for the WGI were compiled mostly during the 1960s, 1970s and 1980s. Since that time period, major changes have taken place in glaciers all over the world (Barry, 2006; Kaser and others, 2006; Lemke and others, 2007). This means that there is an urgent need to update the global glacier database, as mentioned in the strategy of the Global Terrestrial Network for Glaciers (GTN-G) (Haeberli, 2006).

3. Complete detailed glacier parameters such as glacier area, length, elevation, hypsography and ice volume in particular are needed for those glacierized regions that are currently missing from global mass-balance records or have only preliminary data in the WGI, such as the Arctic, Himalaya and Patagonia (Braithwaite, 2002; Dyurgerov and Meier, 2005; WGMS, 2007). Moreover, coupled models for assessing the impact of climate change on glacier evolution (e.g. Gregory and Oerlemans, 1998; Raper and others, 2000; Raper and Braithwaite, 2006) require detailed glacier parameters, in particular glacier area and hypsography.

4. There is a need to incorporate glaciers and ice caps near, or adjacent to, Greenland and Antarctica into global mass-balance and sea-level estimates (Raper and Braithwaite, 2006; Rahmstorf, 2007).

On a global scale, glacier outlines can be derived using automated classification algorithms from multispectral satellite data (e.g. Paul and others, 2002; Paul and Kääb, 2005), as 
recommended in the GTN-G (Haeberli, 2006). The advantages of using remote sensing for glacier delineation are:

1. Sensors such as the Landsat Thematic Mapper (TM) have a relatively large swath width $(185 \mathrm{~km})$ and cover large areas with a medium spatial resolution $(\sim 30 \mathrm{~m})$. Since the end of 2008, the entire United States Geological Survey (USGS) Landsat Archive, containing 35 years of nearly complete global coverage data from the Landsat TM and Landsat Enhanced TM Plus (ETM+) sensors, has been available at no charge from the USGS (http:// landsat.usgs.gov/).

2. For regional-scale studies, satellite imagery has been available from the Advanced Spaceborne Thermal Emission and Reflection Radiometer (ASTER) sensor since 2000. The adequate spatio-temporal resolution (16 days revisit time, $60 \mathrm{~km}$ swath width, $15 \mathrm{~m}$ spatial resolution in the visible and near-infrared (VNIR)), high spectral resolution (14 bands), low cost (free for GLIMS), nearglobal coverage and the capability of acquiring stereo imagery make ASTER a suitable sensor for monitoring glacier parameters, including velocity fields and other applications (Kääb and others, 2003; Racoviteanu and others, 2008b).

3. Automated methods for multispectral glacier classification have been developed and tested in the past decade using Landsat TM and ASTER imagery (Bayr and others, 1994; Sidjak and Wheate, 1999; Paul, 2002; Paul and others, 2002; Kääb and others, 2003, 2005; Paul and Kääb, 2005; Racoviteanu and others, 2008a). These methods are simple, robust and accurate for detection of clean to slightly dirty glacier ice and fresh snow (Albert, 2002; Paul, 2007).

4. Remote-sensing-derived glacier outlines combined with digital elevation models (DEMs) in a geographic information system (GIS) are used to derive topographic glacier inventory parameters such as hypsometry, minimum, maximum and mean elevations in an efficient manner (Klein and Isacks, 1996; Duncan and others, 1998; Kääb and others, 2002; Paul and others, 2002; Paul, 2007).

5. Digital elevation data from remote sensing are increasingly available for conducting glacier change studies at various spatial scales. The global DEM derived from ASTER data (GDEM) was released in July 2009 and is freely available from the Japanese Earth Remote Sensing Data Analysis Center (ERSDAC) at http://www.gdem. aster.ersdac.or.jp/ and from NASA's Land Processes Distributed Active Archive Center (LP DAAC) at: https:// wist.echo.nasa.gov/ wist/api/imswelcome/. Near-global $\left(60^{\circ} \mathrm{N}\right.$ to $\left.57^{\circ} \mathrm{S}\right)$ elevation datasets at $\sim 90 \mathrm{~m}$ spatial resolution are available from the Shuttle Radar Topography Mission (SRTM), flown in February 2000 (Rabus and others, 2003; Farr and others, 2007). Various versions of the SRTM data are available at no cost over the internet. The 'unfinished' product is available from the USGS (http://srtm.usgs.gov/data/obtainingdata.php), but it contains data voids, unedited coastlines, spurious values and some geolocation shifts. The latest version of the SRTM data ('finished' version 3/4) available from the Consultative Group for International Agriculture Research Consortium for Spatial Information (CGIAR-CSI) (e.g. http://www.ambiotek.com/topoview/) is a hydrologically sound DEM where data voids were filled by interpolation.
However, the interpolated regions in the 'finished' version of the SRTM may be inaccurate, so the 'unfinished' version can be used to mask these regions out for further analysis.

\section{The GLIMS initiative}

Based on this increasingly available stock of satellite imagery suitable for global glacier monitoring from space, mapping activities within the GLIMS initiative became widespread (Kargel and others, 2005). As of August 2009, the GLIMS Glacier Database hosted at the National Snow and Ice Data Center (NSIDC) in Boulder, CO, USA, contains digital vector outlines from approximately 83000 glacier entities, covering an area of $262000 \mathrm{~km}^{2}$. Glacier outlines can be downloaded at no cost from the GLIMS website (www.glims.org). The website also has several tools for data query and visualization (Raup and others, 2007a). The glacier delineation techniques applied by individual GLIMS regional centers vary from full manual glacier delineation to various automated techniques based on multispectral classification of ice and snow. A number of GLIMS analysis comparison experiments (GLACE) have demonstrated that the automated methods produce very similar results for sunlit clean ice and snow, while the analyst's interpretation in the delineation of more challenging regions (debris, shadow and lakes) may differ strongly (Raup and others, 2007b). In particular, the methodological interpretation of a glacier as an entity (ice divides, split tributaries and compound glaciers) varies widely, prompting the need for standardized methods. Two of the tutorials generated by the GLIMS team to guide the interpretation of the satellite images and to provide consistency among regional centers are: the GLIMS Analysis Tutorial (B. Raup and S. Khalsa, http://glims.org/MapsAndDocs/assets/GLIMS Analysis_Tutorial-a4.pdf; hereafter GLIMS Analysis Tutorial) and the Illustrated GLIMS Glacier Classification Manual (F. Rau and others, www.glims.org).

Several workshops and meetings have been held within the GLIMS initiative to discuss technical and methodological challenges of glacier mapping and to propose possible solutions. The most recent of these workshops was held during 16-18 June 2008 at the NSIDC. This GLIMS workshop focused on advances and the current state of knowledge related to glacier studies using remote sensing. This paper summarizes the major results of this workshop with an emphasis on definitions, methods and recommendations for satellite-data processing. These are relevant issues for deriving glacier inventory data from spaceborne sensors on a global scale. While the list of proposed methods and recommendations is not comprehensive, our goal here is to provide a starting point for the regional centers in terms of documentation on possible pitfalls in remote-sensing methods for glaciers, along with potential solutions. The following section introduces the workshop topics, remaining challenges and definitions.

\section{GLIMS WORKSHOP TOPICS, CHALLENGES AND DEFINITIONS}

\section{Workshop topics}

During the first 2 days of the 2008 GLIMS workshop, two key topics were addressed by a total of 17 oral presentations and six focus groups: (a) glacier delineation (day 1); and (b) DEM generation and analysis (day 2). Specifically, oral 
Table 1. A selection of oral presentations and topics from the GLIMS workshop held during 16-18 June 2008 at the NSIDC. Presentations point to studies cited in the paper

Ref. Authors
no. Presentation title

1 B. Molnia, A. Crider, P. Geissler, Inventorying the glaciers of Afghanistan E. Lee

2 J. Kargel, R. Furfaro

3 L.M. Andreassen

4 T. Bolch, R. Wheate, B. Menunos

5 F. Paul

6 A. Racoviteanu

$7 \quad$ A. Racoviteanu

8 S.J.S Khalsa, A. Racoviteanu

9 M. Zemp
Glacier lake and glacier debris mapping Deducing area changes from multiple glacier inventories in Jotunheimen, Norway

Challenges of the western Canadian glacier inventory

Glacier mapping from different sensors-technical and methodological challenges

The new Cordillera Blanca glacier inventories from SPOT and ASTER: methodology and challenges Debris-cover mapping in Sikkim Himalaya using ASTER imagery

Comparison of four software packages for DEM generation from ASTER imagery

The compilation of a world inventory of glaciers and ice caps: present status and future challenges
Glacier delineation

Glacier delineation

Glacier delineation, Paul and Andreassen (2009) change detection

Glacier delineation Bolch and others (2007, in press)

Glacier delineation Kääb and others (2002, 2003, 2005); Paul and others (2002, 2004b, 2007); Paul and Kääb (2005); Paul (2007)

Glacier delineation, Raup and others (2007a); change detection Racoviteanu (2008a)

Glacier delineation, Racoviteanu and others

debris cover (2008b)

DEM generation In preparation

Global

WGMS (2008) presentations and working groups focused on algorithm development and comparison on the following topics:

1. mapping clean ice and lakes;

2. mapping ice divides;

3. mapping debris-covered glaciers;

4. assessing changes in glacier area and elevation through comparisons with older data;

5. DEM generation from satellite stereo pairs;

6. accuracy and error analysis.

Day 3 of the workshop was dedicated to summaries and discussion on the topics addressed during the first 2 days. The overarching goal of this workshop was to achieve consensus on algorithms and procedures used for glacier analysis, and to prepare a set of recommendations that can be used by the GLIMS regional centers to avoid inconsistencies in the various glacier datasets included in the GLIMS database. All workshop presentations are listed in Table 1 and are referred to in the text as numbers (e.g. [1] corresponds to reference 1 in Table 1), to distinguish them from bibliographic references.

\section{Challenges}

One aim of this contribution is to describe the most relevant aspects pertaining to glacier outlines derived from satellite data. The focus is on proposing simple, robust and established techniques that work well in most cases. We acknowledge the fact that several special cases, such as debris-covered glaciers, rock glaciers and frozen/turbid lakes, might not be solved with the methods proposed below, and need special attention. Further development of algorithms is ongoing and may provide ways to overcome some of the current problems in the future. However, these are not all described here in detail. The present discussion focuses on remaining challenges with mapping glacier outlines and deriving basic glacier parameters (mostly glacier area and elevation). Additional glacier parameters that can be derived from spaceborne sensors (e.g. mapping of snowlines, flow velocity, debris thickness, glacier lake temperatures and turbidity) are not discussed at length here. Instead, the reader is directed to a number of studies published specifically on these topics: glacier velocity (Berthier and others, 2005; Kääb, 2005), glacier lake temperature (Wessels and others, 2002) and debris thickness (Mihalcea and others, 2008). A thorough discussion on most remote-sensing techniques for glacier mapping can be found in Bishop and others (2000), Bamber and Kwok (2004), Kääb and others (2005), Bamber (2006) and Bamber and Rivera (2007).

In mapping glaciers from satellite imagery within a specific region, three of the most important questions are: (1) Which sensor has the best data for glacier mapping of our region? (2) Which sensor should be used in a particular region? and (3) How can individual glacier entities be identified? While (1) and (2) are related to technical issues and data availability that vary widely with the investigated region and the mapping conditions (e.g. the presence of clouds and snow), (3) is a methodological issue that needs further guidance and is less clear in most cases. Here we present semi-automated methods for mapping clean and debris-covered glacier ice, as well as for delineating ice divides (glacier drainage basins) using available datasets. In many cases, the analyst may also be interested in comparing the new glacier extents with previous assessments derived from other data sources, such as different sensors or, most commonly, older topographic maps. Therefore, this overview includes a discussion on glacier change analysis (area and elevation changes). As DEMs constitute an essential tool for extracting glacier parameters such as length, mean elevations, slope and aspect, as well as for debris-cover mapping and analysis, we also discuss techniques for DEM generation from stereo satellite imagery and give general recommendations for DEM quality assessment. 


\section{Definitions}

Before presenting techniques for glacier mapping, it is important to be clear about what should be mapped. The answer to the simple question 'What is a glacier?' varies with the purpose of the investigation. We rely on definitions developed within the context of the GLIMS project and further discussed during the June workshop. While these definitions are based on other official documents like the UNESCO guidelines for the compilation of the WGI (Müller and others, 1977), they were adapted for the purpose of satellite-based mapping.

\section{GLIMS definition of a glacier}

The GLIMS definition of a 'glacier', tailored to remote sensing and compliant with the World Glacier Monitoring Service (WGMS) standards, states that: 'A glacier or perennial snow mass, identified by a single GLIMS glacier ID, consists of a body of ice and snow that is observed at the end of the melt season, or, in the case of tropical glaciers, after transient snow melts. This includes, at a minimum, all tributaries and connected feeders that contribute ice to the main glacier, plus all debris-covered parts of it. Excluded is all exposed ground, including nunataks. An ice shelf shall be considered as a separate glacier' (GLIMS Analysis Tutorial).

The following selected points from the explanation section should also be mentioned:

1. Bodies of ice above the bergschrund that are connected to the glacier should be considered part of the glacier, because they contribute snow (through avalanches) and ice (through creep flow) to the glacier.

2. A tributary in a glacier system that has been treated (and named) historically as a separate glacier should be included as part of the glacier into which it flows.

3. A stagnant ice mass that is still in contact with a glacier is part of the glacier, even if it supports an old growth forest.

4. If snowfields are identifiable, they should be disconnected from the main glacier. For hydrological purposes, they can be included in the GLIMS Glacier Database under a separate GLIMS glacier ID, but they must be marked as a snowfield.

5. Lateral glacier outlines that might be hidden by seasonal snow or by avalanches should be labeled as preliminary, or even the entire glacier can be excluded. Ice avalanche cones below a glacier terminus (dry-calving) are not part of the glacier.

\section{Debris-covered glaciers}

Debris cover on a glacier varies with thickness, presence or absence of dead ice, type of rock, thermal resistance of the material, etc. (e.g. Mihalcea and others, 2008). Given the high variability in debris characteristics, an attempt to present a standardized definition of debris-covered ice is difficult. Debris on the glacier tongues refers to material incorporated into a glacier by mass-wasting processes, entrainment of subglacial debris and meltout of englacial debris. On a typical debris-covered glacier, such as Khumbu Glacier, Nepal Himalaya, the thickness of the debris ranges from $0 \mathrm{~m}$ at the boundary with clean ice to up to several meters at the glacier snout (Conway and Rasmussen, 2000; Kayastha and others, 2000; Takeuchi and others, 2000). Special cases which do not necessarily fit this category include: thermokarst debris-covered tongues on Tana Glacier, Chugach Mountains, Alaska, USA, and Malaspina Glacier, Alaska, where active debris-covered ice is covered by vegetation [1]; the old, weathered and dirty calving margin of Tasman Glacier, New Zealand (Röhl, 2008), wet debris cover, as well as ice covered completely or partly by debris, where only some patches of ice are visible. Such 'special cases' must be treated separately. All debris-covered parts of the glacier should be mapped if possible.

Rock glaciers are sometimes difficult to distinguish from debris-covered glaciers in medium-resolution satellite imagery. Rock glaciers differ from debris-covered glaciers mainly by a much smaller size and a missing accumulation area. They often reach further down in elevation and their typical ridge-and-furrow surface structure and steep fronts result in a characteristic illumination pattern that can be identified on satellite scenes in most cases. We recommend that rock glaciers be included as a separate category in a glacier inventory when they are easily identified and properly delineated.

\section{Ice divides}

Ice divides are used to define the glacier as an individual entity in a hydrologic sense. This implies that connected units must be separated in the accumulation area where they drain into different basins. The separation of tributaries is more delicate as their connectivity can change over time. From this point of view it makes sense to start with the oldest available datasets (e.g. Little Ice Age extent as mapped from trimlines). According to the GLIMS Analysis Tutorial:

1. If there is no flow between separate parts of a contiguous ice mass, the two parts should, in general, be treated as distinct units, separated at the topographic divide. However, for practical purposes, such an ice mass may be analyzed as a unit at the analyst's discretion, if delineation of the flow divides is impossible or impractical.

2. Any steep rock walls that avalanche snow onto a glacier but do not retain snow themselves should not be included as part of the glacier.

\section{AVAILABLE/PROPOSED METHODS}

\section{Glacier mapping: clean ice and glacier lakes}

Multitemporal satellite imagery from the Landsat TM and ETM+, Système Probatoire pour l'Observation de la Terre (SPOT) and ASTER sensors has been used for automated glacier mapping within the context of the GLIMS initiative in the Swiss Alps (Kääb and others, 2002; Paul and others, 2002), central Asia (Khromova and others, 2003, 2006; Surazakov and Aizen, 2006; Aizen and others, 2007; Bolch, 2007), the Peruvian Andes (Georges, 2004; Racoviteanu and others, 2008a) and the Himalaya (Bolch and Kamp, 2006; Bolch and others, 2008) among others. Most of the papers presented at the GLIMS workshop dealt with glacier mapping algorithms from Landsat and ASTER. Here we present an overview of various methods for automated delineation of clean to slightly dirty glacier ice, with advantages and disadvantages of each algorithm. A more detailed review and comparison of band ratio techniques is provided by Paul and others (2002), Paul and Kääb (2005), Paul (2007) and Racoviteanu and others (2008b). 


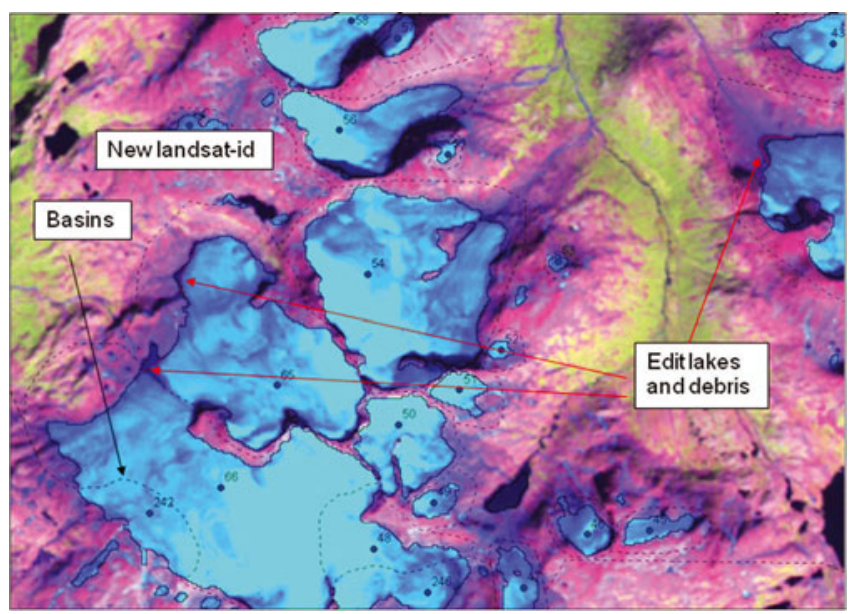

Fig. 1. The new glacier inventory for Jotunheimen, Norway, is based on Landsat TM and ETM+ imagery using a TM3/TM5 band ratio [3]. The false-color composite (FCC) with bands 5, 4, 3 (as RGB) displays glaciers in light blue-green and also shows drainage divides, edited lakes and internal IDs of the glaciers finally selected.

Automatic delineation of clean glacier ice relies on the high reflectivity of snow and ice in the VNIR wavelengths $(0.4-1.2 \mu \mathrm{m})$ compared with a very low reflectivity in the shortwave infrared (SWIR; 1.4-2.5 $\mu \mathrm{m}$ ) (Dozier, 1989; Rees, 2006). In the absence of clouds, snow and ice are distinguished from the surrounding terrain using the VNIR bands from the various sensors available. Commonly used techniques such as TM3/TM5, TM4/TM5, the normalized difference snow index (NDSI) (Hall and others, 1995) and other methods using band ratios take advantage of the spectral uniqueness of snow and ice in the SWIR wavelengths to separate them from non-glacier areas such as rock, soil or vegetation (Bayr and others, 1994). Other simple methods include: manual delineation based on visual interpretation; qualitative digital thresholding based on spectral reflectance (e.g. Rott, 1994); and linear/non-linear functional boundaries for supervised hard classifications (e.g. Aniya and others, 1996).

Several presentations at the GLIMS workshop illustrated techniques for automatic extraction of clean to slightly dirty glacier ice. Three studies [3-5] used Landsat imagery to delineate glaciers over large regions in Norway, western Canada and Baffin Island, respectively. The TM3/TM5 ratio with a threshold of $2.0(\mathrm{TM} 3 / \mathrm{TM} 5>2.0=$ ice/snow $)$ yielded satisfactory results for Norwegian glaciers where debriscovered ice is sparse (Andreassen and others, 2008). An area cutoff of $0.01 \mathrm{~km}^{2}$ and a $3 \times 3$ median filter were applied to obtain glacier outlines for the Jotunheimen region (Fig. 1). Similar methods were employed by Bolch and others [4] to map the glaciers of British Columbia and Alberta (Bolch and others, in press) (Fig. 2). Racoviteanu and others [6, 7] illustrated the use of the NDSI in the Sikkim Himalaya, India, and the Cordillera Blanca, Peru. These studies emphasized the need to choose the threshold manually depending on the scene characteristics (e.g. haze, sun position and topography). For example, for Sikkim, the threshold chosen was 0.7 (NDSI $>0.7=$ snow/ice) (Racoviteanu and others, 2008b), but for Cordillera Blanca the suitable threshold was 0.5-0.6 (Racoviteanu and others, 2008a). The NDSI algorithm correctly classified the clean ice in these two areas, including most of the ice in shadow (Fig. 3), and also

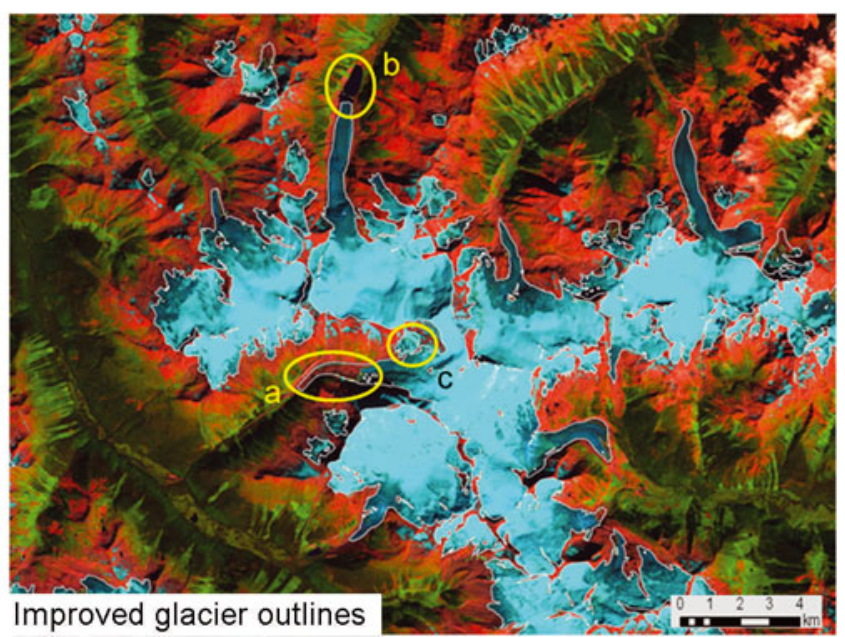

Fig. 2. Results of the western Canada glacier inventory based on Landsat scenes using the TM3/TM5 band ratio. Labels point to: (a) debris cover delineated manually; (b) proglacial lake edited manually; and (c) ice divides that are different in the glacier inventory from the Terrain Resource in Management (TRIM) program (http://ilmbwww.gov.bc.ca/bmgs/pba/trim) [4]. Clouds (white) are clearly recognizable in the FCC.

masked out clouds. However, all band ratio algorithms fail to identify debris-covered ice. Paul [5] further provided a thorough comparison of various techniques, including band ratios TM3/TM5, TM4/TM5, NDSI (TM2-TM5)/(TM2 + TM5), as well as a median filter and dark object subtraction (DOS) for Baffin Island (cf. Paul and Kääb, 2005). For this region, Paul reports the TM 3/5 ratio with an additional threshold in TM1 to be a robust, simple and accurate method, partly even better then manual delineation (i.e. not generalized and consistent for the entire scene). An advantage of this method is that clean ice can be identified even under (optically) thin clouds and in shadow regions. Molnia and others [1] used various masks based on image ratios and thresholding of digital numbers (DN) to construct a glacier inventory of Afghanistan using ASTER and Landsat7 ETM+ imagery from 2001 to 2004. The rather complex classification scheme also distinguishes between snow and ice, but glacier outlines are of the same quality compared with the simpler methods. For delineation of water bodies, some studies proposed the following: using the normalized difference water index (NDWI) [4]; using glacial lake color to aid classification schemes such as band ASTER 1/3 ratio and band 3 intensity [2]; and other new techniques such as sub-pixel mapping using ASTER imagery (Zhang and others, 2004). The accuracy of the glacier outlines derived from image classification using automated methods is generally estimated to be one pixel in most accuracy studies (Congalton, 1991; Zhang and Goodchild, 2002). However, the accuracy estimates may vary widely by region depending on the quality of the images, the methods used and the presence of debris-covered glaciers.

\section{Challenges}

While the above presentations illustrated the effectiveness of NDSI and single-band ratios (such as TM3/TM5 and TM4/ TM5) for fast glacier mapping over large areas, there remain challenges in regions with shadow, clouds, seasonal snow, turbid/frozen/multi-hued proglacial lakes and debris cover. 


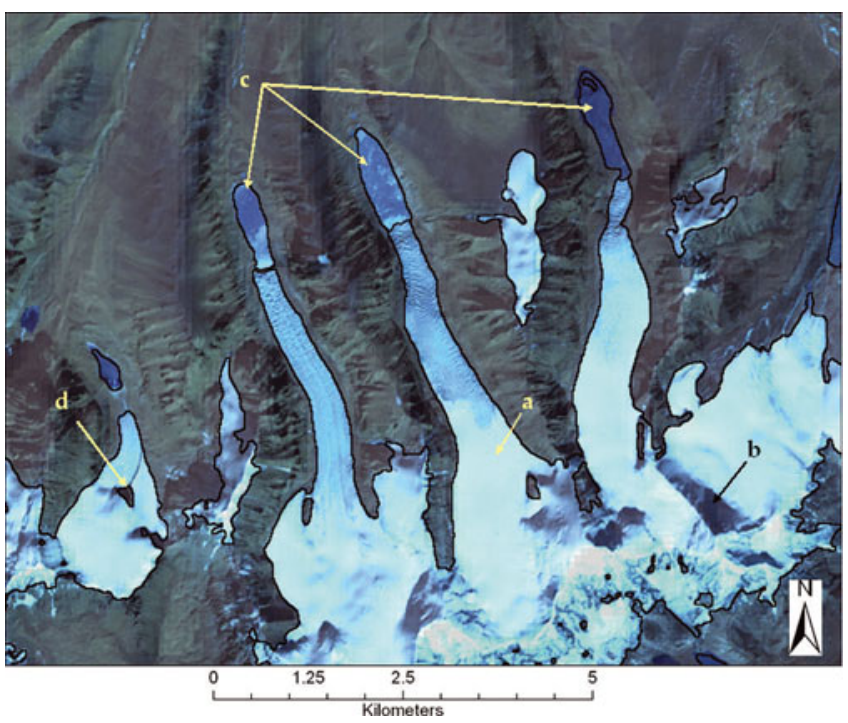

Fig. 3. Results of the classification algorithm for clean ice in northern Sikkim/China from 2001 ASTER imagery. Arrows point to: (a) clean snow and ice classified correctly; (b) shadowed glacier classified correctly; (c) proglacial lakes misclassified as glacier; (d) internal rock correctly delineated (reproduced from Racoviteanu and others, 2008b).

Many presentations in the GLIMS workshop pointed to these challenges. For example, three studies $[4,5,7]$ discussed problems in regions with clouds, late-season snow, perennial ice, proglacial/frozen lakes, regions with crevasses, dark (polluted) ice in shadow and debris cover (Figs 3-5). Figure 4 also indicates regions that are not accurately classified with the TM3/5 ratio (polluted bare ice in shadow and thicker debris cover). Figure 5 indicates the subtle differences in hue for ice-covered lakes compared with flat ice caps which can be present in some regions. In most studies, turbid or frozen glacier lakes and debris-covered glaciers were delineated

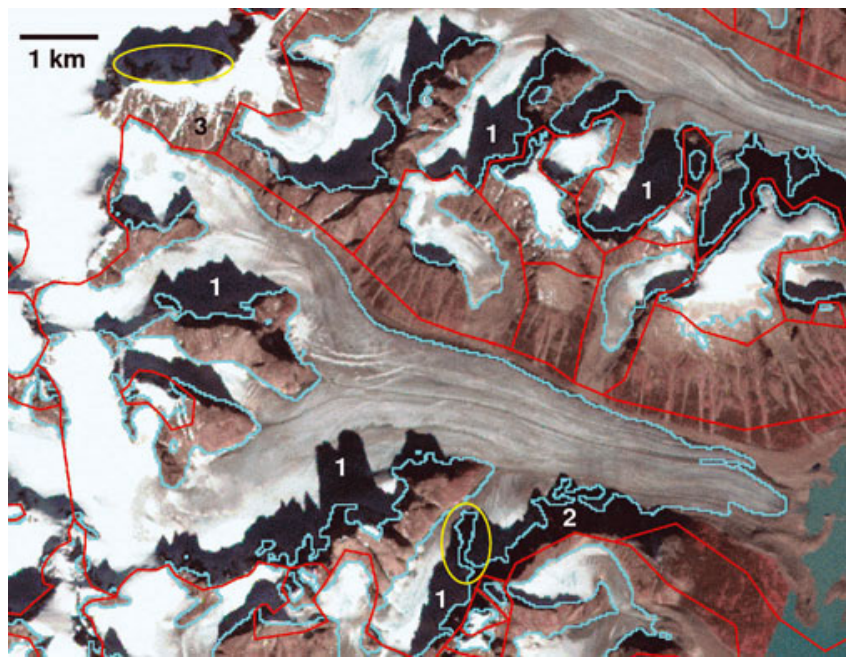

Fig. 4. Mapping accuracy of the TM3/TM5 ratio method in a challenging region near Penny Ice Cap on Baffin Island, Canada [5]. The light-blue lines show the glacier outlines as originally mapped, red lines indicate the glacier basins and yellow circles denote regions that have not been mapped correctly. The numbers indicate: 1 -snow and ice in shadow; 2 -bare rock in shadow; and 3 -snow couloirs

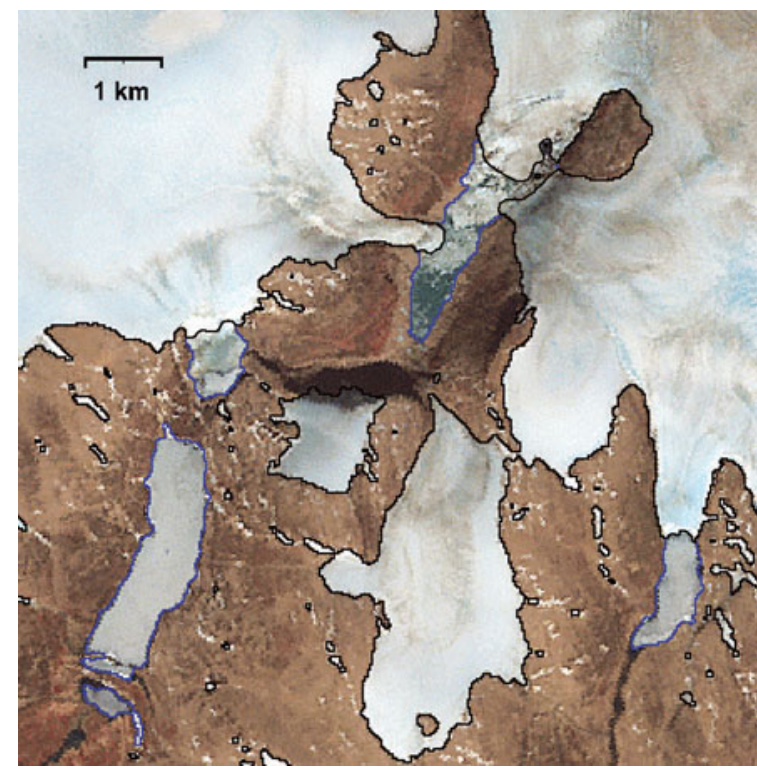

Fig. 5. Illustration of the subtle difference in color between icecovered lakes (blue outline) and clean ice (black) for a system of ice caps on Baffin Island, Canada, using a Landsat ETM+ image from August 2002 in the background [5]

manually using color composites from various VNIR and SWIR band combinations (Figs 2 and 5). Recommendations/ possible solutions with respect to mapping of shadow, clouds, seasonal snow, and turbid/frozen/multi-hued proglacial lakes are briefly presented below. Challenges related to debris-cover mapping were given special consideration in the GLIMS workshop by the working groups and are addressed in a separate section of this paper.

\section{Technical recommendations}

Below is a list of conclusions and technical recommendations for delineation of clean glacier ice. These recommendations may be used as guidelines for choosing one image classification scheme over another, depending on specific cases.

1. Careful selection of satellite scenes at the end of the ablation season is compelling. Scenes where seasonal snow is present outside of glaciers should be avoided [4, 5]. The latter is only possible when the scene is acquired in a year with a very negative glacier mass balance, i.e. when glaciers are free of snow up to the highest elevations. Otherwise, the irregular melt pattern of snowfields might help in discriminating them from the more regularly shaped glacier outlines.

2. Perennial snow banks can be identified by comparing two images that have been acquired several $(\geq 10)$ years apart under similar conditions (e.g. same time of year). In general, perennial snow should not change at all and should be located in topographically preferred regions.

3. In choosing one classification scheme over another, the analyst should consider the end product vs processing time, research vs operational algorithms and acknowledge that operational needs depend also on terrain complexity. 
4. Band ratios and normalized difference methods such as TM2/5, TM3/5, TM4/5 and NDSI are simple and robust and are efficient in delineating clean ice in a timely manner. However, these algorithms might not work properly for dark (polluted) ice in shadow, debriscovered ice is excluded and turbid or frozen lakes are misclassified as glaciers. These regions need to be delineated manually or using algorithms customized and tested for such cases.

5. The image threshold should be iteratively selected based on inspection of shadow regions, which are the most sensitive for the threshold value, before applying it to the whole scene [5].

6. Clouds are highly reflective in the VNIR bands, confounding the classification schemes based on single-band ratio. They are thus classified as 'non-glacier' with any of the above methods [1, 7]. Although clouds are visible in a TM band 5, 4, 3 composite (appearing white), a separate cloud mask might help to identify their location. In most cases, they can be masked out by using a threshold in a SWIR band (AST4 or TM5) where clouds are highly reflective (Dozier, 1989).

7. Delineating the glaciers underneath optically thick clouds remains a challenge. Multiple scenes may be used to eliminate regions that are frequently clouded. Alternatively, glacier identification can be conducted using glaciological knowledge about glacier flow or morphometric analysis in addition to spectral classification [4]. The latter is particularly useful for partly cloud-covered ablation regions, while isolated gaps in the accumulation area due to clouds can be corrected more easily.

8. Turbid proglacial lakes, frozen lakes and supraglacial lakes exhibit a similar band ratio to snow and ice, thus confounding the band ratio classification procedures. While proglacial lakes should not be included as part of the glacier, supraglacial lakes are part of the glacier and must be included. Frozen lakes can only be identified by careful visual inspection (see Fig. 5). A separate classification of lakes is of limited use for glacier delineation, but serves as a valuable input for other investigations.

9. Post-classification steps such as median filters, visual checking for classification errors and manual editing are helpful to further improve classification results. A $3 \times 3$ median filter helps to smooth the resulting glacier outlines and removes noise in regions of shadow or from isolated small snowpatches $[3,5]$.

\section{Glacier mapping: debris-covered ice}

Mapping of debris-covered glaciers is important for accurate determination of glacier area and for further applications that use glacier area as a component. Debris-covered glacier parts confound the band ratio techniques presented above, because the spectral signature of debris is similar to that of surrounding moraines (Paul and others, 2004a). Spectral information alone is thus insufficient to delineate debris cover. Several approaches were developed to address debris-cover mapping by including the characteristic geomorphometric properties of such glaciers as derived from a DEM (Bishop and others, 2001; Paul and others, 2004a), or

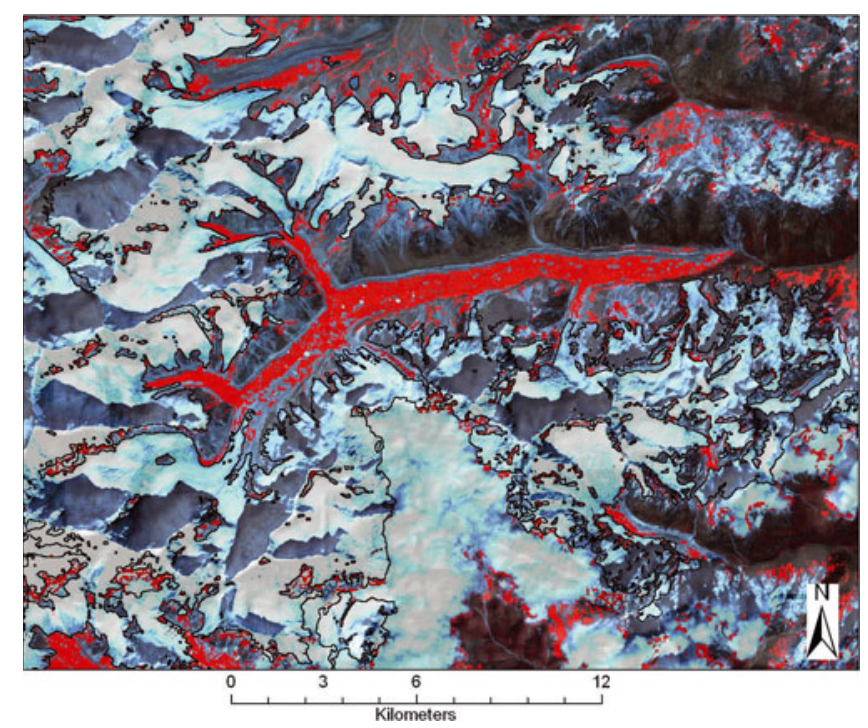

Fig. 6. Results of the debris-covered mapping algorithm using a decision tree for the Sikkim area, Indian Himalaya, based on an ASTER scene from November 2001. Pixels classified as potentially debris-covered are shown in red; clean glacier outlines are shown in black [7].

temperature information derived from thermal bands (Taschner and Ranzi, 2002). While manual digitization of debris-covered glaciers is still a commonly used technique, its application is time-consuming and not practical over large regions. Therefore, current efforts within GLIMS also focus on developing potential algorithms that can be used to guide the glacier mapping in such regions.

\section{Algorithms}

Various semi-automated approaches for mapping of debriscovered glaciers were presented at the GLIMS workshop: band ratios and masks [1], a morphometric approach coupled with thermal information [7] and a neural network approach [2]. Paul and others (2004a) developed a semiautomated method for glacier mapping based on slope characteristics, a map of vegetation cover and a TM4/TM5 band ratio. The algorithms are implemented in a Fortran code and PCI Geomatica modeling scripts (see Paul, 2007), which can be translated into other software. The result depends highly on the quality of the DEM and the type of debris-covered glaciers being mapped (e.g. a smooth surface without melt ponds). Bolch and others (2007) tested various morphometric approaches coupled with thermal information. A supervised classification with a slope threshold yielded satisfactory results for the Khumbu region in Nepal (Bolch and others, 2007) and can always be used as a starting point when other algorithms are not available. One study [7] presented a morphometric approach coupled with thermal information using ASTER data in a decision tree classifier. Binary (yes/no) masks are created for different classes (such as ice/snow, vegetation, bare land and clouds) from single-band thresholding or band ratios (NDSI). Thresholds are chosen manually and are then applied to the entire image to eliminate regions unsuitable for the occurrence of debris cover. This approach proved useful for mapping the debris-covered glaciers in the Sikkim Himalaya, although some noise needs to be eliminated from the final map (Fig. 6). 


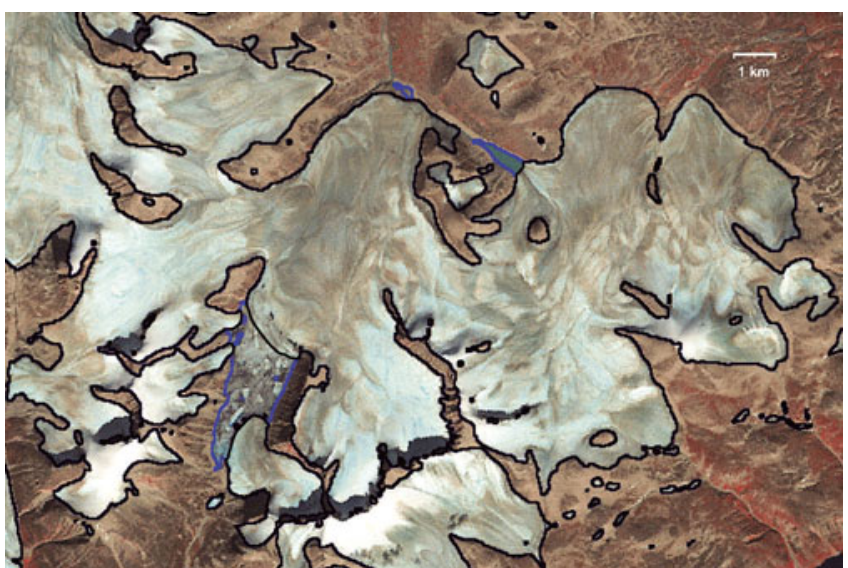

Fig. 7. A system of ice caps with complex topology on Baffin Island, Canada, as seen on a Landsat ETM+ satellite image from August 2002 (bands 4, 3, 2 as RGB). Black lines indicate automatically generated glacier outlines; blue lines enclose (partly ice-covered) lakes and have been deleted manually.

\section{Challenges}

Currently, there is no single best algorithm for debris-cover mapping that can be applied to large regions without some manual corrections of the resulting outlines. The various methods for mapping debris-covered glaciers have not yet been compared and a superior method has thus not yet emerged. The basic consideration for applying a semiautomated method over fully manual correction is the required workload, which varies by region with respect to characteristics and number of the debris-covered glaciers, DEM availability and the complexity of the method. For example, complicated algorithms such as neural networks or Fuzzy C Mean clustering classifications may provide more accurate results, especially for various types of debris cover (Bishop and others 1999), but the long processing time may limit their applicability over large regions.

Remaining challenges in debris-cover mapping relate to accurate identification of the glacier terminus, the separation from stagnant glacier parts and, in some areas, the lack of a high-resolution DEM needed to apply the specified algorithms. Stereo viewing of the original satellite bands, which strongly enhances visual perception, may be helpful in interpreting subtle morphological details (personal communication from V. Aizen, 2008). However, one of the greatest remaining challenges is the validation of the existing debris-cover algorithms. Possibilities for validation include use of velocity maps derived from feature tracking, field campaigns using radar techniques or drilling, georeferenced ground photos or calculation of thickness changes from DEM differencing. Given that it may be difficult to locate the boundary of a debris-covered glacier even in the field (e.g. Haeberli and Epifani, 1986), the uncertainty in mapping debris-covered glaciers from satellite data remains high no matter what technique is used and this should be acknowledged in any glacier inventory and analysis derived from it.

\section{Technical recommendations}

1. In choosing an algorithm for debris-cover mapping, the analyst should consider the software availability, the type of image being analyzed and the type of terrain.
2. Given the complexity of the debris-cover mapping methods, the algorithms presented above may be used as a guide or a starting point for manual delineation.

3. Over large regions, manual delineation of debriscovered glacier ice is very time-consuming (about 5 min per glacier) and the analyst might consider relying on automated algorithms while acknowledging the errors associated with these algorithms.

4. Visual identification of debris-covered parts may be strongly enhanced by utilizing stereo-viewing techniques on the original images (e.g. using ASTER bands $3 \mathrm{~N}$ and 3B).

5. Surface slope and vegetation maps may work well in most cases. If thermokarst features are present (hummocky surface), the analyst should either use a different method, or try to first fill the holes in the DEM (sinkholes) using various available interpolating methods.

6. Terrain curvature can work well for delineating debriscovered regions when marked moraines are visible on the DEM.

7. Using the highest-resolution DEM available is not always advisable because of the noise in the data and the additional features that become visible, so terrain smoothing may be useful in some cases before applying the algorithms.

8. 'Special cases' mentioned above should be identified and treated specifically, possibly by using manual delineation.

9. Visual inspection of the derived debris-cover maps and final editing are always required.

\section{Ice-divide mapping}

The purpose of ice-divide mapping is to identify glacier entities in an objective and consistent manner, for hydrologic applications (e.g. glacier runoff) and glaciological applications (e.g. change detection). Generally, ice divides may be identified faster using semi-automated algorithms (hydrologic modeling tools) than by visual interpretation, but a DEM is required in the former case. Three basic considerations need to be addressed: (1) where to place the divide; (2) how to delineate it automatically; and (3) how to match ice divides from recent imagery with formerly used ice divides derived from topographic maps. Also, the type of glacier must be considered (e.g. ice field, ice cap, outlet glacier, mountain/valley glacier and glacieret) before a separation is made. Ice fields consist of a central ice mass (with nunataks) from which several 'outlet glaciers' originate. An ice cap is a dome-shaped mass of ice, not divided by topography, which may also have 'outlet glaciers', and is most commonly found on top of volcanoes or in Arctic regions (Müller and others, 1977). For both types it can be very challenging to find or assign divides in the accumulation area and thus the analyst may opt to treat the entire system as one entity in the beginning. This might apply, for example, for the rather complex ice-cap system on Baffin Island, which is depicted in Figure 7. Valley or mountain glaciers are confined to a valley and may have tributaries. These glacier types usually have easily identifiable upper divides due to the presence of rock outcrops (see Fig. 4), but determining whether tributaries should be included may be 
challenging, depending on whether these tributaries contribute substantially to the mass of the glacier. Several methods for delineating ice divides for the above four types were illustrated in oral presentations at the workshop and are summarized below.

\section{Algorithms}

A first starting point for ice-divide mapping is a flowdirection and/or watershed grid derived from the DEM. This can be used in many cases to digitize the ice divides accurately (Paul and Andreassen, 2009) but is rather timeconsuming. Other automated methods were also presented at the workshop. One study [4] described an approach for ice-divide delineation which consists of: (1) generating a buffer around the glacier; (2) calculating basins based on a DEM; and (3) removing all basins without a glacier (Fig. 8). An algorithm developed by Manley (2008) was illustrated for the Afghanistan and Cordillera Blanca glaciers, respectively [1, 6]. Manley's algorithm consists of creating 'contiguous ice' polygons, identifying ice divides for them using DEM analysis, then 'cutting' the contiguous ice polygons along the ice divides. The steps are: (1) calculating the median elevation for each ice mass; (2) isolating the 'toes' of the ice masses, where each toe is identified by ice gridcells with elevations lower than the median elevation for the ice mass; (3) using the toes as 'pour points' (starting points for watershed analysis) to identify separate glacier basins (watersheds); (4) identifying complex ice masses (those with more than one toe, and only those larger than a variable area cut-off, depending on the number of toes per ice mass); (5) isolating basin areas within the complex ice masses ('complex basins'); (6) converting the complex basins to polygons; and (7) overlaying the basin polygons on the ice polygons. The result of the algorithm depends on the choice of less-than-median-elevation for toes that act as 'pour points' for glacier basins. 'Pour points' can be digitized manually or derived automatically (Schiefer and others, 2008).

The methods presented above rely on the availability of an appropriate DEM, which is not always available for some glacierized regions. Furthermore, it must be mentioned that DEMs based on optical imagery often have inaccuracies in the accumulation zones of the glaciers (where the ice divides are situated) due to low or almost no contrast on the snow-covered areas (Toutin, 2008; Svoboda and Paul, 2009). In the absence of a DEM, illumination differences and glaciological knowledge about glacier flow can be applied for a first estimation of the ice-divide position (cf. Paul and Kääb, 2005). Ice divides derived in this way can be revised later in the digital database when DEM information becomes available.

\section{Challenges}

The types of difficulties faced in applying the ice-divide algorithms depend on whether the ice bodies are ice caps or ice fields, complex topologies or compound glacier types. Such cases need to be addressed separately in most cases. It is important to acknowledge that the choice of an ice-divide mapping method depends on the intended application. Consistency with ice divides from various years is desirable for change analysis studies, such as area changes, to minimize errors. However, it is necessary to consider that ice divides may change and glaciers may disintegrate, requiring the delineation of new ice divides [4]. The analyst

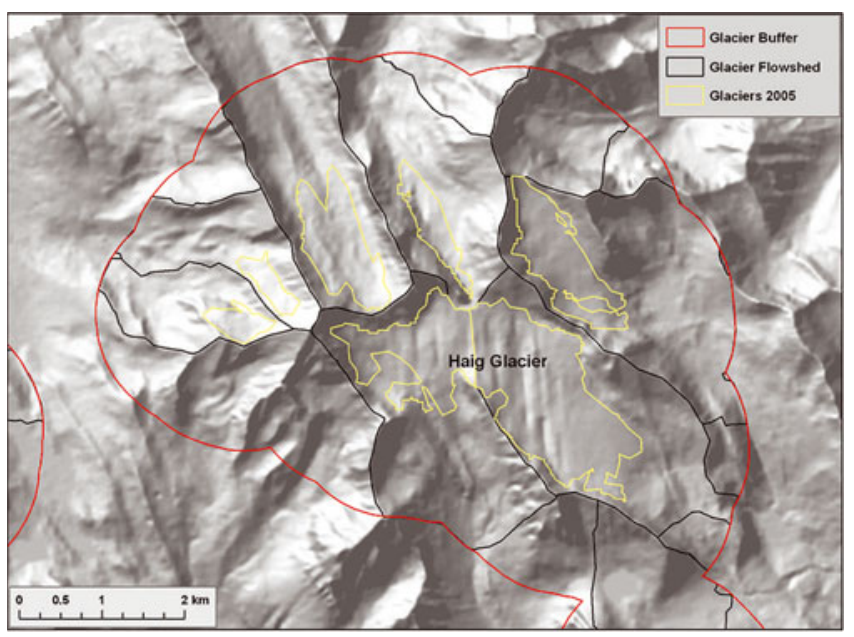

Fig. 8. Schematic illustration of the ice-divide mapping algorithm using DEM analysis in Western Canada. The background shows a shaded relief from the used TRIM DEM [4].

can start with the largest possible (e.g. Little Ice Age) extent, which can be used subsequently to track the changes of the entire system.

\section{Technical recommendations}

The choice of an ice-divide algorithm requires a DEM for watershed modeling, and glacier outlines derived from topographic maps or satellite imagery. The following recommendations are based largely on a case study in Baffin Island (Paul and Kääb, 2005) as well as on other participants' expertise compiled during the working session on ice-divide mapping:

To a large extent, choosing a location for the ice divide depends on the purpose of the glacier inventory and the glacier type (e.g. ice caps of varying complexity). Four scenarios were identified:

1. When a former glacier inventory already exists and a comparison with these former glacier extents is envisaged, ice divides should be placed at the same locations as in the former inventory. When the old ice divides are not available digitally but have to be digitized from printed (sketch) maps, a larger error must be considered (which might even be larger than the real area change).

2. If the purpose of glacier mapping is a hydrologic one (e.g. to calculate specific runoff from a catchment), the glaciers should be divided in a hydrologic way. Given an accurate orthorectification of the satellite data, readily available digitized catchments should be used. To some extent it might be possible to use major hydrologic divides instead of those related to a lower stream order.

3. When no former inventory is available, glaciers should be divided in a more glaciological sense. However, principal rules of a hydrologic numbering scheme (see Müller and others, 1977) should also be considered. Where printed maps with point data from the WGI are available (e.g. as for Baffin Island), they should be considered as an identifier for individual entities. 
Table 2. Summary of features and functionality of four software packages capable of generating DEMs from ASTER stereo pairs [8]. Version of Silcast used by the LP DAAC was not available; products ordered 3 April 2008. GcPs: ground control points; TPs: tie points

\begin{tabular}{|c|c|c|c|c|}
\hline Feature & $\mathrm{PCl}(\mathrm{v} 10.0)$ & ENVI (v4.5) & LPS (v9.2) & Silcast \\
\hline Uses both L1a and L1b scenes as input & Y & Y & $\mathrm{N}$ & $\mathrm{N}$ \\
\hline Pixel level DEM quality info & Y & $\mathrm{N}$ & Y & $\mathrm{N}$ \\
\hline Imports GCPs and TPs & Y & Y & Y & $\mathrm{N}$ \\
\hline $\begin{array}{l}\text { Control over process (min. correlation, window } \\
\text { size, smoothing, etc.) }\end{array}$ & Excellent & $\begin{array}{l}\text { Good (but auto hole fill } \\
\text { and smooth) }\end{array}$ & Superior & $\begin{array}{l}\text { None (auto hole fill } \\
\text { and smooth) }\end{array}$ \\
\hline Auto TiePoint accuracy & Moderate & Excellent & Good & Unknown \\
\hline Correlation success on low-contrast surfaces & Good & Good & Poor (known bug) & Good \\
\hline Tools to identify and correct bad TPs and GCPs & Good & Good & Excellent & $\mathrm{N} / \mathrm{A}$ \\
\hline Adaptability to unique features of each scene & Good & Good & Excellent & Excellent \\
\hline DEM quality assessment metrics & Good & Good & Excellent & None \\
\hline DEM editing tools & Good & Excellent & Excellent & None \\
\hline Learning curve, ease of use & Moderate & Easy, moderate & Steep, difficult & Simple \\
\hline Speed & Slow & Fast & Moderate & Fast \\
\hline
\end{tabular}

4. Ice caps can be divided into distinct units when they are well defined. When they are more compact or the units are not clear, they should not be subdivided (see Fig. 7).

The algorithms to be applied for digitizing ice divides mostly depend on the availability of a (reliable) DEM. Two scenarios were identified:

1. When no DEM is available, a best guess of the location should be made based on illumination differences and glaciological knowledge about glacier flow. Uncertain divides in the accumulation region can be indicated by straight lines and a lower positional accuracy in the metadata table for the respective line segment.

2. When a DEM is available, the first step is the calculation of a flow direction grid that allows delineating divides manually. A second step is the calculation of watersheds or upslope area from given pour points. A third step is the application of the above-mentioned automated methods.

\section{DEM generation}

DEMs are used by glaciologists to derive glacier parameters such as length (using flow direction functions), terminus elevation, median elevation, hypsometric information and glacier flow patterns. When combined with glacier outlines, DEMs are also useful for defining ice divides from flow direction grids and watershed analysis in a semi-automated fashion [4, 5], and for orthorectification of satellite imagery. DEMs from different time-steps may be used to determine changes in glacier surface elevation at decadal scales (e.g. Surazakov and Aizen, 2006; Larsen and others, 2007; Racoviteanu and others, 2007; Schiefer and others, 2007; Paul and Haeberli, 2008). While DEM accuracy is a key issue for glaciological applications, there is no consensus within the glaciological community regarding the best software package and methodology for generating DEMs from satellite imagery. This section describes the most commonly available commercial DEM-generation software packages that are designed to work with satellite-image stereo pairs, and attempts to describe the strengths and weaknesses of each. The goal here is not necessarily to advise on which package works best under various conditions, or even to provide relative error assessments, but only to provide some characteristics of the packages and to list some implications for glacier studies. Most of these points were summarized in one presentation in the GLIMS workshop [8] and were discussed in the DEM working group.

Commercial software currently available for DEM generation from satellite-image stereo pairs includes: Geomatica from PCl Geomatics, ENVI from ITT Visual Information Solutions, Leica Photogrammetric Suite (LPS) from ERDAS, Silcast from Sensor Information Laboratory Corp., Desktop Mapping System (DMS) from R-WEL and Photomod from Racurs. Recent efforts have been undertaken to validate DEMs derived from ASTER (Kääb, 2002; Toutin, 2002; Hirano and others, 2003; Bolch, 2004; Eckert and others, 2005; Fujisada and others, 2005; Racoviteanu and others, 2007), SPOT (Krupnik, 2000; Berthier and others, 2007) and SRTM (Sun and others, 2003; Berthier and others, 2006; Carabajal and Harding, 2006). Other studies focused on comparing the SRTM DEMs with ASTER DEMs (Fujita and others, 2008; Hayakawa and others, 2008). For a detailed review of the methods, algorithms and available commercial software to extract elevation from ASTER satellite imagery, and its various applications in geoscientific applications, the reader is directed to a recent review article by Toutin (2008).

There is a need for further accuracy assessment in the specific context of glacier studies. One study presented in the GLIMS workshop [8] processed three ASTER scenes containing glaciers in different regions of the world (Cordillera Blanca in Peru, Lahul-Spiti in western Himalaya, and the Antarctic Peninsula) using four different packages: $\mathrm{PCI}, \mathrm{ENVI}$, Silcast and LPS. The resulting DEMs were compared and the results and experiences in using these packages are summarized in Table 2. The packages vary widely in sophistication and ease of use, with LPS requiring the most training before all its features can be properly utilized and Silcast requiring nothing more than an input file. Although LPS offers the most options for optimizing the DEM generation process, it does not uniformly produce the best DEM. We believe that this is in part due to the fact that in the version we were using (9.2) the pre-processing routines for radiometric corrections were not working properly. In summary, there is no one package that performs best under all circumstances-each has its strengths and weaknesses. The trade-offs include performance, cost, control and ease of use. 


\section{Challenges}

Challenges in DEM extraction from optical satellite imagery are manifold and include among others: lack of ground control due to logistical, cultural and/or political issues; lack of contrast over accumulation areas of the glacier or in regions of shadow, exacerbated by suboptimal instrument gains; the presence of clouds on the satellite scene being analyzed; and obscuration of terrain due to the looking direction of the stereo sensor. Users must be cognizant of errors inherent in DEMs derived from remote-sensing imagery, such as elevation and slope biases (Kääb and others, 2003; Berthier and others, 2006; Racoviteanu and others, 2007; Fujita and others, 2008; Paul, 2008).

For some glaciological applications, a one-time modernera global DEM of adequate spatial resolution and wellcharacterized errors would be desirable. As mentioned earlier, the DEM derived from the SRTM has found application within the community, although the biases, voids and the 3 arcsec resolution limit its utility. The Silcast software has been used to produce a GDEM at 1 arcsec resolution from about 30000 ASTER scenes. The product is due for completion mid-2009 (http://www.ersdac.or.jp/ GDEM/E/). A recent study focused on comparing a prerelease version of the GDEM and the SRTM-3 (Hayakawa and others, 2008). A validation summary of the ASTER GDEM produced by the Ministry of Economy, Trade and Industry (METI), Japan, and NASA was recently released and is available from https://lpdaac.usgs.gov. This study concludes that the overall accuracy of the global ASTER DEM can be taken to be approximately $20 \mathrm{~m}$ at $95 \%$ confidence interval. While the accuracy of carefully generated DEMs from satellite data might be higher than the near-global products (SRTM, GDEM), the latter might be well suited to derive detailed glacier inventory data on a global scale. Further studies comparing the different DEM sources and software packages quantitatively will be performed in the future.

\section{Technical recommendations}

Quality control of the DEMs is essential before they are applied for glacier studies. Acceptable errors depend on the intended application. These include, in order of increasing accuracy requirement: extracting topographic information (slope/aspect) which does not change rapidly, orthorectification of satellite imagery, hypsometry, extracting glacier parameters (e.g. minimum/mean/maximum elevations), and geodetic mass balance (from DEM differencing). DEMs can be derived from topographic maps by interpolating either points or contour lines digitized from these maps. The accuracy of the resulting DEM is largely dependent on the type of terrain and the interpolation method used (Racoviteanu and others, 2007; Kääb, 2008). DEMs from satellite imagery are constructed by stereocorrelation procedures with the above mentioned specialized software packages. Below is a summary of steps that may be used to minimize DEM errors and to conduct quality control on DEMs for both topographic maps and satellite imagery.

1. In choosing a satellite scene for DEM generation, the following should be considered:

the quality of source imagery such as channel gains (high gains provides detail in shadow regions, but may result in saturation over the accumulation area); the degree of cloudiness, their possible elevation and maybe a predefined cloud mask;

the date of acquisition: for area change detection and mass-balance applications, the satellite scene should be acquired at the end of the ablation season with minimal seasonal snow;

the choice of spatial resolution influences the output DEM. The cell size should be chosen according to terrain characteristics (higher resolution for rugged terrain, lower resolution for smooth terrain).

2. Ground-control points (GCPs) acquired in the field for DEM generation and/or evaluation should be spread across the scene, away from steep slopes and have similar slope/aspect to the glacier. The placement of the antenna must be included in GCPs from the field as this can induce vertical errors of a few meters.

3. Methods of assessing the accuracy of DEMs derived from either map or satellite imagery include:

examining the root-mean-square error in the vertical coordinate (RMSEz) with respect to GCPs;

identifying artefacts such as blunders and outliers, using hillshades, profile curvature, elevation histograms, DEMs with coarser cell size and slope maps;

performing a trend assessment on the DEM to detect biases;

comparing transects from the DEM with field data;

specifically for DEMs constructed from topographic maps using interpolation, spot elevation from the DEMs can be compared with points extracted from the original contours to determine the accuracy of each interpolation method;

for DEMs created from satellite imagery, software reports such as score channel and error maps;

for a reliable DEM, the orthorectified stereo bands (e.g. ASTER $3 \mathrm{~N}$ and $3 \mathrm{~B}$ ) should match exactly. DEM errors that may occur due to mismatching can be calculated by dividing the shift through the stereo ratio of the sensor (e.g. 0.6 for ASTER);

when a DEM is created from mosaicking several scenes together, examining discontinuities at mosaic seams will provide information on the accuracy of the orthorectification process and DEM extraction.

4. Some suggestions for improving the quality of the resulting DEMs include:

pre-processing (selection of cloud-free satellite scenes with good contrast over snow and ice), stretching, sharpening and filtering;

ensuring a good distribution of GCPs and avoiding questionable ones;

downsampling of the epipolar image pairs;

post-processing/editing such as hole filling from DEMs with coarser resolution, interpolation, and terrain smoothing. 


\section{Change detection}

Multitemporal analysis is used to detect changes in various glacier parameters such as area, length, elevation, proglacial lakes, debris cover and internal rock. Important issues relating to change detection include accurate and consistent orthorectification, flowline digitization, the date of acquisition of the data used for DEM generation, and their spatial resolution. Regarding the latter, it must be emphasized that medium-resolution satellite DEMs (ASTER/SRTM) are more useful for assessing changes in glacier surface elevation for large glaciers and on decadal timescales. High-resolution DEMs (e.g. derived from aerial photogrammetry or lidar) can also be used for small glaciers (area $<1 \mathrm{~km}^{2}$ ) and/or for shorter timescales (annual changes). Further details on the detection of glacier area changes can also be found in Paul and Hendriks (2009).

Examples of deriving glacier area changes from multitemporal analysis of satellite images in the context of the GLIMS initiative are numerous. A small selection of such studies, conducted by some of the GLIMS researchers, include Bayr and others (1994), Kääb and others (2002), Paul and others (2002, 2004b, 2007), Hall and others (2003), Khromova and others (2003, 2006), Bolch and Kamp (2006), Bolch (2007) and Racoviteanu and others (2008a). The approach of deriving changes in glacier surface elevations from multiple DEMs was used in several studies on the basis of historical topographic maps and DEMs derived from SPOT imagery (e.g. Berthier and others, 2004, 2007), SRTM (Rignot and others, 2003; Surazakov and Aizen, 2006; Larsen and others, 2007; Racoviteanu and others, 2007; Schiefer and others, 2007; Paul and Haeberli, 2008), ASTER (Rivera and Casassa, 1999; Kääb, 2008) and laser altimetry (Arendt and others, 2002). A combination of optical imagery (SPOT HRV, Landsat TM and ASTER) and synthetic aperture radar (SAR) (European Remote-sensing Satellite (ERS), RADARSAT) data, as well as high-resolution DEMs derived from the Panchromatic Remote-sensing Instrument for Stereo Mapping aboard the Japanese Advanced Land Observing Satellite (ALOS PRISM) launched in 2006 and Corona (Narama and others, 2007; Bolch and others, 2008), provide potential for thickness change estimations over small regions, but they are not particularly useful for achieving global DEM coverage.

\section{Challenges}

Various presentations [1, 4, 6] addressed challenges in glacier change detection studies and comparison with old topographic data, posed by inconsistencies in the various data sources and processing steps. Such challenges include: geometric changes in glacier topography such as rock outcrops, splitting or disintegration of glaciers; and inconsistencies arising from comparing data from various sources, for example satellite-derived data vs data derived from topographic maps, or comparison with the point data as stored in the WGI. The largest sources of error in the estimates of area changes may come from errors in the baseline data sources, mostly in the case of old data from topographic maps. For example, two studies conducted in the Cordillera Blanca (Georges, 2004; Racoviteanu and others, 2008a) point out that the glacierized area in the 1970 baseline inventory was overestimated by as much as $10 \%$ due to seasonal snow, thus resulting in a larger estimated area change from 1970 to the present. Racoviteanu and others (2008a) point to apparent growth in glacier areas of as much as $100 \%$ due to digitizing errors in the baseline glacier inventory of the Cordillera Blanca, mostly in debris-covered areas. Other challenges for area change detection are posed by use of poor-quality satellite images, the presence of seasonal snow in the accumulation region of glaciers and the presence of debris cover on the glacier surface. Challenges in vertical change detection using multiple DEMs could be related to inconsistencies in horizontal/ vertical datums in the various elevation datasets being compared or penetration of the radar beam into dry snow for interferometric SAR (InSAR)-derived DEMs (Farr and others, 2007). For example, Racoviteanu and others (2007) report an apparent glacier thickening at high elevations of Nevado Coropuna, Peru, due to known errors in the baseline topographic map. Such errors are common when the topographic map was derived from aerial photography with low contrast in the accumulation areas, and pose a major problem in elevation change studies. To minimize such inconsistencies, a few recommendations are listed below.

\section{Recommendations}

For calculation of glacier area changes between two points in time, the following issues should be considered:

1. When possible, area change calculations should be derived from similar datasets (e.g. same type of satellite imagery).

2. The change should be calculated by subtracting the obtained total sizes in each analyzed year and not by digitally subtracting the glacier maps.

3. To minimize inconsistencies, the use of the same type of data by the same surveyor and the same analysis methods is recommended.

4. There should be consistency in upper glacier boundaries, internal rocks, debris cover and snow cover among various inventories used for comparison. If inconsistencies exist in parts of the dataset, selecting a subsample of the glacier dataset for detailed change analysis is recommended (Racoviteanu and others, 2008a).

5. If glacier outlines from different sources are compared (e.g. one set of outlines derived from older topographic maps and the other from satellite imagery), special care must be taken that exactly the same entities are compared. In such cases and for analysis purposes, drainage divides should be kept constant for both datasets, thus ignoring any changes in the position of the ice divides [4] (Paul and others, 2007; Racoviteanu and others, 2008a; Paul and Andreassen, 2009).

In assessing changes in elevation from multiple DEMs, the following points may be considered:

1. Any physical changes on the glacier surface over the period of evaluation (e.g. snow amount, lake formation) should be considered.

2. Change detection analysis should be avoided in regions where DEM values are interpolated.

3. It should be taken into account that DEMs from optical stereo are often inaccurate in accumulation areas (e.g. Schiefer and others, 2007; VanLooy and Forster, 2008). 
4. The distribution of vertical errors between two DEMs with respect to elevation and slope should be quantified.

5. Elevation differences should be computed on nonglacierized terrain vs glacierized terrain and care should be taken that they are as flat as possible to avoid resampling artefacts (Paul, 2008).

6. If difference maps look like hillshade maps, this indicates a geolocation registration error (shift).

7. When using spaceborne altimetry data (ICESat) or InSAR (ERS, SRTM) in evaluating DEM accuracy, errors arising from signal saturation and beam penetration should be considered.

8. Changes in topographic parameters such as minimum or mean glacier elevation through time are difficult to quantify if there were strong changes in glacier geometry, such as separation of tributaries or disintegration of ice masses, as noted in various studies (Paul and others, 2004a; Kulkarni and others, 2007; Racoviteanu and others, 2008a). The related rules and recommendations for such calculations have yet to be defined.

\section{ERRORS IN REMOTE SENSING OF GLACIERS}

Given that the assessments of glacier area are sensitive to the quality of the data used to derive them, the issue of uncertainty and its propagation in glacier delineation based on remote sensing deserves proper consideration. So far, only a few glaciological studies (Hall and others, 2003; Raup and others 2007b) have provided careful evaluations of uncertainty in glacier mapping using ground data. At the core of the problem is the lack of systematic ground-control data (such as DGPS measurements) to evaluate errors in the derived glacier outlines. In most cases, all glacier outlines are validated and corrected against a ground truth (e.g. visual comparison with the satellite image). Since an independent ground truth is often not available, standard measures of accuracy no longer apply (see Svoboda and Paul, 2009). However, it is possible to differentiate between certain types of error, and for some of them accuracy measures are available.

In remote sensing of glaciers, the main sources of uncertainty may arise from: (1) positional errors (geocoding, GCPs); (2) classification errors (misidentified features); (3) processing errors (e.g. from digitization, coordinate precision, attribute data, 'sliver' polygons resulting from overlay operations); and (4) conceptual errors (e.g. glacier definition issues such as ice divides, perennial snowfields, minimum size, and fragmentation). While errors of type (1), (2) and (3) are generally small and can be calculated by standard statistical methods (Congalton, 1991; Zhang and Goodchild, 2002), conceptual errors can be quite large but difficult to quantify. In order to identify the latter, several socalled GLIMS analysis comparison experiments (GLACE) have been performed (Raup and others, 2007b). They helped to design the guidelines of the GLIMS Analysis Tutorial, which could be seen as a large step forward regarding the consistency of the GLIMS database entries. Presently, it is possible to store errors of type (1) and (3) for each glacier in the database. Type (2) and (4) errors currently can be identified (at least partly) by visual inspection of the outlines using 3-D digital overlays or stereo viewing.

\section{CONCLUSIONS AND GENERAL RECOMMENDATIONS}

The GLIMS workshop held in Boulder, CO, USA, in June 2008 focused on the current state of glacier monitoring from satellite imagery in the context of the GLIMS initiative. Presentations and working groups addressed algorithms and challenges for glacier delineation and DEM generation and analysis. The workshop participants also aimed at establishing protocols and providing a set of tools and algorithms for glacier delineation and DEM generation, which can be used by GLIMS regional centers. As a result of the workshop, the GLIMS algorithm page hosted at http://glims.org will be updated to contain code, scripts and processing steps that will be shared within the GLIMS community.

Currently, fully automated inventorying of individual glaciers from threshold ratio satellite images is hampered by challenges encountered with mapping of debris-covered glaciers, separation of seasonal snow from perennial snow and glacier ice, and finding the correct location of ice divides [9]. Topographic shadowing effects, clouds and water bodies can be corrected by visual interpretation and manual editing. Many workshop presentations demonstrated that the use of digital terrain information in a GIS greatly facilitates automated procedures of image analysis, data processing and modeling/interpretation of newly available information. General recommendations with respect to glacier delineation and analysis in a remote-sensing and GIS environment are given below:

1. Refer to published tutorials and algorithms, such as the GLIMS Analysis Tutorial.

2. Compile and make use of additional material that facilitates the glaciological interpretation, such as oblique photos, topographic maps, published glacier inventory data in digital (coordinates) or analog (books) form, and ground photos.

3. Use the freely available and already orthorectified scenes from Landsat TM/ETM+ (USGS, http://landsat.usgs.gov) to check for geolocation errors.

4. Start with the most simple image classification method and test more advanced methods when the required input (e.g. a DEM) is available.

5. Select thresholds for band ratios that minimize the workload needed for post-processing (i.e. manual editing).

6. Thoroughly document the applied techniques (e.g. thresholds, filters, and manual interpretation).

7. Keep one original image classification result and apply any corrections (e.g. debris delineation and water body separation) on a copy.

8. Apply necessary manual corrections to remove regions that should not be taken into account for glacier area (e.g. seasonal snow and proglacial lakes).

9. Change assessments should be carried out at decadal scales between (dated) trimlines of the Little Ice Age ( 1850s) and $\sim 2000$, with respect to the global baseline inventory.

10. Metadata are essential to face the challenges of using different mapping techniques (e.g. maps vs aerial photos vs satellite images). 


\section{Future work}

Current efforts within the GLIMS initiative focus on further systematizing the process of extracting glacier boundaries from satellite imagery. We expect that these efforts will lead to a more consistent and higher-quality database of glaciers that can be used for many scientific purposes. We are additionally focusing on integrating the GLIMS Glacier Database with other global glacier databases, such as the WGI. Challenges in achieving this task are posed by: difficulty in matching up corresponding records due to poor geolocation in some cases, differences in snow-firn-ice differentiation among the different databases, disintegration and disappearance of glaciers, missing meta-information, different methodologies and data formats between WGI and GLIMS and other databases, and limited capacities of monitoring services. To minimize inconsistencies in various databases in the future and to aid the process of integration of the various databases, future steps should focus on: defining key regions that are relevant for climate change, sea-level rise, hydrological questions and natural hazards; providing guidelines and algorithms for calculation of glacier parameters from digital sources; conducting detailed inventories at decadal scale in these regions; linking annual in situ measurements with decadal remote-sensing data for change assessments; providing a better definition of priorities and workflows for the different datasets; and improving the coordination of efforts between the key players such as the WGMS, NSIDC, GLIMS, international organizations and the wider scientific community.

\section{ACKNOWLEDGEMENTS}

The GLIMS team at NSIDC is supported by NASA awards NNG04GF51A and NNG04GM09G. A. Racoviteanu's research is supported by a US National Science Foundation (NSF) doctoral dissertation improvement award (NSF DDRI award BCS 0728075) and a NASA Earth System Science Fellowship (NNX06AF66H). The work of F. Paul has been performed within the framework of the European Space Agency project GlobGlacier (21088/07/I-EC). We thank $\mathrm{V}$. Aizen and T. Bolch for their constructive comments. We are grateful to all the workshop participants for their feedback, discussion and ongoing input to the GLIMS project.

\section{REFERENCES}

Aizen, V.B., V.A. Kuzmichenok, A.B. Surazakov and E.M. Aizen. 2007. Glacier changes in the Tien Shan as determined from topographic and remotely sensed data. Global Planet. Change, 56(3-4), 328-340.

Albert, T.H. 2002. Evaluation of remote sensing techniques for icearea classification applied to the tropical Quelccaya ice cap, Peru. Polar Geogr., 26(3), 210-226.

Andreassen, L.M., F. Paul, A. Kääb and J.E. Hausberg. 2008. Landsatderived glacier inventory for Jotunheimen, Norway, and deduced glacier changes since the 1930s. Cryosphere, 2(2), 131-145.

Aniya, M., H. Sato, R. Naruse, P. Skvarca and G. Casassa. 1996. The use of satellite and airborne imagery to inventory outlet glaciers of the Southern Patagonia Icefield, South America. Photogramm. Eng. Remote Sens., 62(12), 1361-1369.

Arendt, A.A., K.A. Echelmeyer, W.D. Harrison, C.S. Lingle and V.B. Valentine. 2002. Rapid wastage of Alaska glaciers and their contribution to rising sea level. Science, 297(5580), 382-386.
Bamber, J. 2006. Remote sensing in glaciology. In Knight, P.G., ed. Glacier science and environmental change. Oxford, Blackwell Publishing, 370-382.

Bamber, J.L. and R. Kwok. 2004. Remote sensing techniques. In Bamber, J.L. and A.J. Payne, eds. Mass balance of the cryosphere: observations and modelling of contemporary and future changes. Cambridge, Cambridge University Press, 59-113.

Bamber, J.L. and A. Rivera. 2007. A review of remote sensing methods for glacier mass balance determination. Global Planet. Change, 59(1-4), 138-148.

Barnett, T.P., J.C. Adam and D.P. Lettenmaier. 2005. Potential impacts of a warming climate on water availability in snowdominated regions. Nature, 438(7066), 303-309.

Barry, R.G. 2006. The status of research on glaciers and global glacier recession: a review. Progr. Phys. Geogr., 30(3), 285-306.

Bayr, K.J., D.K. Hall and W.M. Kovalick. 1994. Observations on glaciers in the eastern Austrian Alps using satellite data. Int. J. Remote Sens., 15(9), 1733-1752.

Berthier, E., Y. Arnaud, D. Baratoux, C. Vincent and F. Rémy. 2004. Recent rapid thinning of the Mer de Glace glacier derived from satellite optical images. Geophys. Res. Lett., 31(17), L17401. (10.1029/2004GL020706.)

Berthier, E. and 7 others. 2005. Surface motion of mountain glaciers derived from satellite optical imagery. Remote Sens. Environ., 95(1), 14-28.

Berthier, E., Y. Arnaud, C. Vincent and F. Rémy. 2006. Biases of SRTM in high-mountain areas: implications for the monitoring of glacier volume changes. Geophys. Res. Lett., 33(8), L08502. (10.1029/2006GL025862.)

Berthier, E., Y. Arnaud, R. Kumar, S. Ahmad, P. Wagnon and P. Chevallier. 2007. Remote sensing estimates of glacier mass balances in the Himachal Pradesh (Western Himalaya, India). Remote Sens. Environ., 108(3), 327-338.

Bishop, M.P., B.L. Hickman and J.F. Shroder, Jr. 1999. High resolution satellite imagery and neural networks for information extraction in a complex mountain environment. Geocarto Int., 14(2), 17-26.

Bishop, M.P., J.S. Kargel, H.H. Kieffer, D.J. MacKinnon, B.H. Raup and J.F. Shroder, Jr. 2000. Remote-sensing science and technology for studying glacier processes in high Asia. Ann. Glaciol., 31, 164-170.

Bishop, M.P., R. Bonk, U. Kamp, Jr and J.F. Shroder, Jr. 2001. Terrain analysis and data modeling for alpine glacier mapping. Polar Geogr., 25(3), 182-201.

Bolch, T. 2004. Using ASTER and SRTM DEMs for studying glaciers and rockglaciers in northern Tien Shan. In Dzhanaleeva, G.M., ed. Proceedings Part I of the Conference 'Teoretischeskije $i$ Prikladnyje Problemy geografii na rubeschje Stoletij' [Theoretical and Applied Problems of Geography on a Boundary of Centuries], 8-9 June 2004, Almaty, Kazakhstan. Almaty, Ministerstvo Obrazovanijai Nauki Respubliki Kazakhstan, 254-258.

Bolch, T. 2007. Climate change and glacier retreat in northern Tien Shan (Kazahkstan/Kyrgyzstan) using remote sensing data. Global Planet. Change, 56(1-2), 1-12.

Bolch, T. and U. Kamp. 2006. Glacier mapping in high mountains using DEMs, Landsat and ASTER data. In Kaufmann, V. and W. Sulzer, eds. Proceedings of the 8th International Symposium on High Mountain Remote Sensing Cartography. Graz, Karl Franzens University, 13-24. (Grazer Schriften der Geographie und Raumforschung 41.)

Bolch, T., M.F. Buchroithner, A. Kunert and U. Kamp. 2007. Automated delineation of debris-covered glaciers based on ASTER data. In Gomarasca, M.A., ed. Geolnformation in Europe. Proceedings of the 27th EARSeL Symposium, 4-7 June, 2007, Bozen, Italy. Rotterdam, Millpress, 403-410.

Bolch, T., M. Buchroithner, T. Pieczonka and A. Kunert. 2008. Planimetric and volumetric glacier changes in the Khumbu Himal, Nepal, since 1962 using Corona, Landsat TM and ASTER data. J. Glaciol., 54(187), 592-600. 
Bolch, T., B. Menounos and R. Wheate. In press. Landsat-based inventory of glaciers in western Canada, 1985-2005. Remote Sensing of Environment.

Bradley, R.S., M. Vuille, H.F. Diaz and W. Vergara. 2006. Threats to water supply in the tropical Andes. Science, 312(5781), 1755-1756.

Braithwaite, R.J. 2002. Glacier mass balance: the first 50 years of international monitoring. Progr. Phys. Geogr., 26(1), 76-95.

Carabajal, C.C. and D.J. Harding. 2006. SRTM C-band and ICESat laser altimetry elevation comparisons as a function of tree cover and relief. Photogramm. Eng. Remote Sens., 72(3), 287-298.

Congalton, R.G. 1991. A review of assessing the accuracy of classifications of remotely sensed data. Remote Sens. Environ., 37(1), 35-46.

Conway, H. and L.A. Rasmussen. 2000. Summer temperature profiles within supraglacial debris on Khumbu Glacier, Nepal. IAHS Publ. 264 (Symposium at Seattle 2000 - Debris Covered Glaciers), 89-97.

Dozier, J. 1989. Spectral signature of alpine snow cover from the Landsat Thematic Mapper. Remote Sens. Environ., 28(1-3), 9-22.

Duncan, C.C., A.J. Klein, J.G. Masek and B.L. Isacks. 1998 Comparison of late Pleistocene and modern glacier extents in central Nepal based on digital elevation data and satellite imagery. Quat. Res., 49(3), 241-254.

Dyurgerov, M.B. and M.F. Meier. 2005. Glaciers and the changing Earth system: a 2004 snapshot. Boulder, CO, University of Colorado. Institute of Arctic and Alpine Research. (INSTAAR Occasional Paper 58.)

Eckert, S., T. Kellenberger and K. Itten. 2005. Accuracy assessment of automatically derived digital elevation models from ASTER data in mountainous terrain. Int. J. Remote Sens., 26(9), 1943-1957.

Farr, T.G. and 17 others. 2007. The Shuttle Radar Topography Mission. Rev. Geophys., 45(2), RG2004. (10.1029/ 2005RG000183.)

Fujisada, H., G.B. Bailey, G.G. Kelly, S. Hara and M.J. Abrams. 2005. ASTER DEM performance. IEEE Trans. Geosci. Remote Sens., 43(12), 2707-2714

Fujita, K., R. Suzuki, T. Nuimura and A. Sakai. 2008. Performance of ASTER and SRTM DEMs, and their potential for assessing glacial lakes in the Lunana region, Bhutan Himalaya. J. Glaciol. 54(185), 220-228

Georges, C. 2004. 20th century glacier fluctuations in the tropical Cordillera Blanca, Peru. Arct. Antarct. Alp. Res., 36(1), 100-107.

Gregory, J.M. and J. Oerlemans. 1998. Simulated future sea-level rise due to glacier melt based on regionally and seasonally resolved temperature changes. Nature, 391(6666), 474-476.

Haeberli, W. 2006. Integrated perception of glacier changes: a challenge of historical dimensions. In Knight, P.G., ed. Glacier science and environmental change. Oxford, Blackwell, 423-430.

Haeberli, W. and F. Epifani. 1986. Mapping the distribution of buried glacier ice - an example from Lago delle Locce, Monte Rosa, Italian Alps. Ann. Glaciol., 8, 78-81.

Hall, D.K., G.A. Riggs and V.V. Salomonson. 1995. Development of methods for mapping global snow cover using Moderate Resolution Imaging Spectroradiometer (MODIS) data. Remote Sens. Environ., 54(2), 127-140.

Hall, D.K., K.J. Bayr, W. Schöner, R.A. Bindschadler and J.Y.L. Chien. 2003. Consideration of the errors inherent in mapping historical glacier positions in Austria from ground and space (1893-2001). Remote Sens. Environ., 86(4), 566-577.

Hayakawa, Y.S., T. Oguchi and Z. Lin. 2008. Comparison of new and existing global digital elevation models: ASTER G-DEM and SRTM-3. Geophys. Res. Lett., 35(17), L17404. (10.1029/ 2008GL035036.)

Hirano, A., R. Welch and H. Lang. 2003. Mapping from ASTER stereo image data: DEM validation and accuracy assessment. ISPRS J. Photogramm. Remote Sens., 57(5-6), 356-370.

Kääb, A. 2002. Monitoring high-mountain terrain deformation from repeated air- and spaceborne optical data: examples using digital aerial imagery and ASTER data. ISPRS J. Photogramm. Remote Sens., 57(1-2), 39-52.

Kääb, A. 2005. Combination of SRTM3 and repeat ASTER data for deriving alpine glacier flow velocities in the Bhutan Himalaya. Remote Sens. Environ., 94(4), 463-474.

Kääb, A. 2008. Glacier volume changes using ASTER satellite stereo and ICESat GLAS laser altimetry. A test study on Edgeøya, Eastern Svalbard. IEEE Trans. Geosci. Remote Sens., 46(10), 2823-2830.

Kääb, A., F. Paul, M. Maisch, M. Hoelzle and W. Haeberli. 2002. The new remote-sensing-derived Swiss glacier inventory: II. First results. Ann. Glaciol., 34, 362-366.

Kääb, A. and 6 others. 2003. Glacier monitoring from ASTER imagery: accuracy and application. EARSeL eProc., 2(1), 43-53.

Kääb, A. and 10 others. 2005. Remote sensing of glacier- and permafrost-related hazards in high mountains: an overview. Natur. Hazards Earth Syst. Sci. (NHESS), 5(4), 527-554.

Kargel, J.S. and 16 others. 2005. Multispectral imaging contributions to global land ice measurements from space. Remote Sens. Environ., 99(1-2), 187-219.

Kaser, G., J.G. Cogley, M.B. Dyurgerov, M.F. Meier and A. Ohmura. 2006. Mass balance of glaciers and ice caps: consensus estimates for 1961-2004. Geophys. Res. Lett., 33(19), L19501. (10.1029/2006GL027511.)

Kayastha, R.B., Y. Takeuchi, M. Nakawo and Y. Ageta. 2000. Practical prediction of ice melting beneath various thickness of debris cover on Khumbu Glacier, Nepal using a positive degreeday factor. IAHS Publ. 264 (Symposium at Seattle 2000 - DebrisCovered Glaciers), 71-81.

Khromova, T.E., M.B. Dyurgerov and R.G. Barry. 2003. Latetwentieth century changes in glacier extent in the Ak-shirak Range, Central Asia, determined from historical data and ASTER imagery. Geophys. Res. Lett., 30(16), 1863. (10.1029/ 2003GL017233.)

Khromova, T.E., G.B. Osipova, D.G. Tsvetkov, M.B. Dyurgerov and R.G. Barry. 2006. Changes in glacier extent in the eastern Pamir, Central Asia, determined from historical data and ASTER imagery. Remote Sens. Environ., 102(1-2), 24-32.

Klein, A.G. and B.L. Isacks. 1996. Glaciers: tracking change in the central Andes Mountains. GIS World, 9(10), 48-52.

Krupnik, A. 2000. Accuracy assessment of automatically derived digital elevation models from SPOT images. Photogramm. Eng. Remote Sens., 66(8), 1017-1023.

Kulkarni, A.V. and 6 others. 2007. Glacial retreat in Himalaya using Indian remote sensing satellite data. Current Sci., 92(1), 69-74.

Larsen, C.F., R.J. Motyka, A.A. Arendt, K.A. Echelmeyer and P.E. Geissler. 2007. Glacier changes in southeast Alaska and northwest British Columbia and contribution to sea level rise. J. Geophys. Res., 112(F1), F01007. (10.1029/2006JF000586.)

Lemke, P. and 10 others. 2007. Observations: changes in snow, ice and frozen ground. In Solomon, S. and 7 others, eds. Climate change 2007: the physical science basis. Contribution of Working Group I to the Fourth Assessment Report of the Intergovernmental Panel on Climate Change. Cambridge, etc., Cambridge University Press, 337-383.

Manley, W.F. 2008. Geospatial inventory and analysis of glaciers: a case study for the eastern Alaska Range. In Williams, R.S., Jr and J.G. Ferrigno, eds. Satellite image atlas of glaciers of the world. Denver, CO, United States Geological Survey, K424-K439. (USGS Professional Paper 1386-K.)

Meier, M.F. and 7 others. 2007. Glaciers dominate eustatic sealevel rise in the 21st century. Science, 317(5841), 1064-1067.

Mihalcea, C. and 7 others. 2008. Using ASTER satellite and groundbased surface temperature measurements to derive supraglacial debris cover and thickness patterns on Miage Glacier (Mont Blanc Massif, Italy). Cold Reg. Sci. Technol., 52(3), 341-354.

Müller, F., T. Caflisch and G. Müller. 1977. Instructions for the compilation and assemblage of data for a world glacier inventory. Zürich, IAHS(ICSI)/UNEP/UNESCO. Temporary Technical Secretariat for the World Glacier Inventory, ETH-Zürich. 
Narama, C., A. Kääb, T. Kajiura and K. Abdrakhmatov. 2007. Spatial variability of recent glacier area and volume changes in central Asia using Corona, Landsat, ASTER and ALOS optical satellite data. Geophys. Res. Abstr., 9, EGU2007-A-08178.

Paul, F. 2002. Changes in glacier area in Tyrol, Austria, between 1969 and 1992 derived from Landsat 5 thematic mapper and Austrian glacier inventory data. Int. J. Remote Sens., 23(4), 787-799.

Paul, F. 2007. The new Swiss glacier inventory 2000 - application of remote sensing and GIS. Schr. Phys. Geogr. Univ. Zürich, 52.

Paul, F. 2008. Correspondence. Calculation of glacier elevation changes with SRTM: is there an elevation-dependent bias? J. Glaciol., 54(188), 945-946.

Paul, F. and L.M. Andreassen. 2009. A new glacier inventory for the Svartisen region (Norway) from Landsat ETM+ data: challenges and results. J. Glaciol., 55(192), 607-618

Paul, F. and W. Haeberli. 2008. Spatial variability of glacier elevation changes in the Swiss Alps obtained from two digital elevation models. Geophys. Res. Lett., 35(21), L21502. (10.1029/2008GL034718.)

Paul, F. and J. Hendriks. In press. Area change detection of glaciers. In Pellika, P. and W.G. Rees, eds. Remote sensing of glaciers. London: Taylor \& Francis.

Paul, F. and A. Kääb. 2005. Perspectives on the production of a glacier inventory from multispectral satellite data in Arctic Canada: Cumberland Peninsula, Baffin Island. Ann. Glaciol., 42, 59-66.

Paul, F., A. Kääb, M. Maisch, T. Kellenberger and W. Haeberli. 2002. The new remote-sensing-derived Swiss glacier inventory. I. Methods. Ann. Glaciol., 34, 355-361.

Paul, F., C. Huggel and A. Kääb. 2004a. Combining satellite multispectral image data and a digital elevation model for mapping debris-covered glaciers. Remote Sens. Environ., 89(4), 510-518.

Paul, F., A. Kääb, M. Maisch, T. Kellenberger and W. Haeberli. 2004b. Rapid disintegration of Alpine glaciers observed with satellite data. Geophys. Res. Lett., 31(21), L21402. (10.1029/ 2004GL020816.)

Paul, F., A. Kääb and W. Haeberli. 2007. Recent glacier changes in the Alps observed from satellite: consequences for future monitoring strategies. Global Planet. Change, 56(1-2), 111-122.

Rabus, B., M. Eineder, A. Roth and R. Bamler. 2003. The shuttle radar topography mission - a new class of digital elevation models acquired by spaceborne radar. ISPRS J. Photogramm. Remote Sens., 57(4), 241-262.

Racoviteanu, A., W.F. Manley, Y. Arnaud and M. Williams. 2007. Evaluating digital elevation models for glaciological applications: an example from Nevado Coropuna, Peruvian Andes. Global Planet. Change, 59(1-4), 110-125.

Racoviteanu, A.E., Y. Arnaud, M.W. Williams and J. Ordoñez. 2008a. Decadal changes in glacier parameters in the Cordillera Blanca, Peru, derived from remote sensing. J. Glaciol., 54(186), 499-510.

Racoviteanu, A.E., M.W. Williams and R.G. Barry. 2008b. Optical remote sensing of glacier characteristics: a review with focus on the Himalaya. Sensors, 8(5), 3355-3383.

Rahmstorf, S. 2007. A semi-empirical approach to projecting future sea-level rise. Science, 315(5810), 368-370.

Raper, S.C.B. and R.J. Braithwaite. 2006. Low sea level rise projections from mountain glaciers and icecaps under global warming. Nature, 439(7074), 311-313.

Raper, S.C.B., O. Brown and R.J. Braithwaite. 2000. A geometric glacier model for sea-level change calculations. J. Glaciol., 46(154), 357-368.

Raup, B., A. Racoviteanu, S.J.S. Khalsa, C. Helm, R. Armstrong and Y. Arnaud. 2007a. The GLIMS geospatial glacier database: a new tool for studying glacier change. Global Planet. Change, 56(1-2), 101-110.

Raup, B. and 11 others. 2007b. Remote sensing and GIS technology in the Global Land Ice Measurements from Space (GLIMS) Project. Comput. Geosci., 33(1), 104-125.
Rees, W.G. 2006. Remote sensing of snow and ice. Boca Raton, FL, CRC Press.

Rignot, E., A. Rivera and G. Casassa. 2003. Contribution of the Patagonian icefields of South America to sea level rise. Science, 302(5644), 434-437.

Rivera, A. and G. Casassa. 1999. Volume changes on Pio XI glacier, Patagonia: 1975-1995. Global Planet. Change, 22(1-4), 233-244.

Röhl, K. 2008. Characteristics and evolution of supraglacial ponds on debris-covered Tasman Glacier, New Zealand. J. Glaciol., 54(188), 867-880

Rott, H. 1994. Thematic studies in alpine areas by means of polarimetric SAR and optical imagery. Adv. Space Res., 14(3), 217-226.

Schiefer, E., B. Menounos and R. Wheate. 2007. Recent volume loss of British Columbian glaciers, Canada. Geophys. Res. Lett., 34(16), L16503. (10.1029/2007GL030780.)

Schiefer, E., B. Menounos and R. Wheate. 2008. An inventory of morphometric analysis of British Columbia glaciers, Canada. J. Glaciol., 54(186), 551-560.

Sidjak, R.W. and R.D. Wheate. 1999. Glacier mapping of the Illecillewaet icefield, British Columbia, Canada, using Landsat TM and digital elevation data. Int. J. Remote Sens., 20(2), 273-284.

Singh, P. and L. Bengtsson. 2004. Hydrological sensitivity of a large Himalayan basin to climate change. Hydrol. Process., 18(13), 2363-2385.

Singh, P. and S.K. Jain. 2002. Snow and glacier melt in the Satluj River at Bhakra Dam in the western Himalayan region. Hydrol. Sci. J., 47(1), 93-106.

Singh, P., S.K. Jain and N. Kumar. 1997. Estimation of snow and glacier-melt contribution to the Chenab River, western Himalaya. Mt. Res. Dev., 17(1), 49-56.

Sun, G., K.J. Ranson, V.I. Kharuk and K. Kovacs. 2003. Validation of surface height from shuttle radar topography mission using shuttle laser altimeter. Remote Sens. Environ., 88(4), 401-411.

Surazakov, A.B. and V.B. Aizen. 2006. Estimating volume change of mountain glaciers using SRTM and map-based topographic data. IEEE Trans. Geosci. Remote Sens., 44(10), 2991-2995.

Svoboda, F. and F. Paul. 2009. A new glacier inventory on southern Baffin Island, Canada, from ASTER data: I. Applied methods, challenges and solutions. Ann. Glaciol., 51(53) (see paper in this issue).

Takeuchi, Y., R.B. Kayastha and M. Nakawo. 2000. Characteristics of ablation and heat balance in debris-free and debris-covered areas on Khumbu Glacier, Nepal Himalayas in the pre-monsoon season. IAHS Publ. 264 (Symposium at Seattle 2000 - DebrisCovered Glaciers), 53-61.

Taschner, S. and R. Ranzi. 2002. Comparing the opportunities of Landsat-TM and Aster data for monitoring a debris covered glacier in the Italian Alps within the GLIMS project. In Proceedings of 22nd International Geoscience and Remote Sensing Symposium (IGARSS 2002), 24-28 June, 2002, Toronto, Ontario, Canada. Vol. 2. Piscataway, NJ, Institute of Electrical and Electronic Engineers, 1044-1046.

Toutin, T. 2002. Three-dimensional topographic mapping with ASTER stereo data in rugged topography. IEEE Trans. Geosci. Remote Sens., 40(10), 2241-2247.

Toutin, T. 2008. ASTER DEMs for geomatic and geoscientific applications: a review. Int. J. Remote Sens., 29(7), 1855-1875.

VanLooy, J.A. and R.R. Forster. 2008. Glacial changes of five southwest British Columbia icefields, Canada, mid-1980s to 1999. J. Glaciol., 54(186), 469-478.

Wessels, R.L., J.S. Kargel and H.H. Kieffer. 2002. ASTER measurement of supraglacial lakes in the Mount Everest region of the Himalaya. Ann. Glaciol., 34, 399-408.

World Glacier Monitoring Service (WGMS). 1989. World glacier inventory: status 1988, ed. Haeberli, W., H. Bösch, K. Scherler, G. Østrem and C.C. Wallén. IAHS(ICSI)/UNEP/UNESCO, World Glacier Monitoring Service, Zürich. 
WGMS. 2007. Glacier Mass Balance Bulletin No. 9 (2004-2005), ed. Haeberli, W., M. Hoelzle and M. Zemp. ICSU(FAGS)/ IUGG(IACS)/UNEP/UNESCO/WMO, World Glacier Monitoring Service, Zürich.

WGMS. 2008. Global glacier changes: facts and figures, ed. Zemp, M., I. Roer, A. Kääb, M. Hoelzle, F. Paul and W. Haeberli. United Nations Environment Programme, World Glacier Monitoring Service, Zürich.
Zhang, H., Q. Lin, S. Liu and J. Shi. 2004. Sub-pixel lake mapping in Tibetan Plateau. In Proceedings of 24th International Geoscience and Remote Sensing Symposium (IGARSS 2004), 20-24 September 2004, Anchorage, Alaska, USA. Vol. 5. Piscataway, NJ, Institute of Electrical and Electronics Engineers, 3073-3076.

Zhang, J. and M.F. Goodchild. 2002. Uncertainty in geographical information. London, Taylor \& Francis. 